Perry Nodelman teaches English at the University of Winnipeg and is the editor of Children's Literature Association Quarterly. He has published numerous articles on children's literature and is currently at work on a booklength study of the art of picture books.

I Am the Cheese, p. 187

\section{Perry Nodelman}

\section{Robert Cormier does a number}

"But," thinks Adam Farmer at a key point in I Am the Cheese, "this is absurd." Adam is right. In Robert Cormier's novel, this apparently ordinary boy discovers that his ordinary life was mere fabrication, and the truth beneath the lies is an improbable stew of secret documents, spies, murders, and assumed identities. But most readers are too caught up in the novel to think about how improbable it is. I Am the Cheese is like the "Numbers" it describes - the practical jokes Adam's friend Amy Hertz invents to persuade innocent bystanders that something improbable really did happen. Cormier tells us "Amy Hertz was beautiful to watch when she was doing a Number. The process had to be carried out seriously, with no hint of mischief" (p. 60). Cormier carries out his own number just as seriously, just as beautifully.

Cormier tells us that Amy "always withheld information about the Numbers until the last possible moment, stretching out the drama" (p. 182). He does that himself in the novel. The reviews quoted on the back cover of the paperback edition speak of how "gripping" it is, of how "the suspense builds relentlessly," of how "everything builds and builds to a fearsome climax." Generally, suspense arises from uncertainty about what will happen next in an orderly chain of events; but while readers of $I \mathrm{Am}$ the Cheese experience uncertainty about what fact they will discover next, the facts are all about past events. Our attention is focused not on what happens next, but rather, on what has happened already; in that way, I Am the Cheese is more like a mystery novel than a suspense thriller. 
Cormier makes much use of the world "clue" throughout, and I A $\mathrm{m}$ the Cheese demands of its readers the detached, investigative attitude engendered by the sort of mystery novels that contain clues - the sort of novel Adam's father tells him about: "I'll show you a mystery novel in which the first two letters of the first word of the first chapter hold the secret to the book" (p. 43). When I first read that sentence, I couldn't resist the temptation Cormier had so adroitly offered; I immediately turned to the first page, and looked at the first two letters. They were I and A: not much help at all in my figuring out what was going on. But I did think about it, and I did test out numerous possibilities involving puns and anagrams. I became a logical, detached detective.

But despite my detachment, I still felt anxiety. I wanted to know what was happening, not just to satisfy my intellectual puzzlement about an intricate mystery, but also because I felt genuinely disoriented and confused, genuinely involved in that uncertainty we call suspense. The genius of the novel is that it is both logical puzzle and exciting thriller, that it engenders detachment and involvement at the same time.

Cormier achieves that paradoxical combination by focusing our attention on the past-making us think about what might have happened, as mysteries do-while at the same time keeping us ignorant of the present that mysterious past led to. Most mystery novels begin by showing us things as they are now: the dead body in the library, a telephone found in the freezer. The detective reads back from those present circumstances to determine how they came to be. But in $I A m$ the Cheese, we don't know what Adam's present circumstances are; figuring out what they are comes to be part of our concern. We must both try to solve the mystery and be unsure about what the effects of it are-or if, indeed, there were any effects at all. Since we do not know what effects the mysterious past we are trying to understand led to, we act less with the cool certainty of mystery novel detectives than with the anxiety of confused people asked to think logically about incomplete information.

That sounds uncomfortable - and it is. Cormier cleverly makes us accept and enjoy our confusion by providing one genuine past, a set of events that happened and are now over, and 
what appear to be two different presents that that past led to. The story of Adam's bicycle trip to Rutterburg is in the present tense; but so are the sections labelled as tapes. Since we know that two such dissimilar sets of events cannot both be equally present, we must ask which precedes the other. It is possible that something happened in the past that led to Adam's confused state of mind as he embarks on the bicycle trip, and that something then happened on the bicycle trip that led to his apparent therapy as it appears on the tapes. But it is also possible that something happened in the past that led to the therapy, and that it is a partially recovered Adam who sets off to visit his father after his sessions with Brint. With our attention focused on sorting such things out, looking for clues and making guesses, we accept our uncertainty about present circumstances as part of the pleasure of the mystery.

Just as important, we let Cormier do his Number; for of course, the real truth is right before our eyes. The two presents are both equally present, just as they appear in the novel. That Adam is both undergoing his sessions with Brint and riding his bicycle to Vermont at the same time is the one possibility we don't consider; Cormier cannot allow us to consider it, for it depends on our knowledge that the bike trip is a fantasy, knowledge that is the key to the entire mystery. He deflects our attention from the literal truth of the novel, the impeccably chronological ordering of events that seem to have no chronology, by making them seem to have no chronology.

How Cormier manipulates readers into believing the wrong things and ignoring the right ones is fascinating to explore; and I believe that why he does it is the key to the meaning of the novel. But such an exploration is not easy. The Number only works once, for each reader on a first reading. A second reading, with knowledge both of what happened in the past and of what is happening in the present, is a different experience. Now the novel seems filled with clues, with obvious evidence of what seemed incomprehensible before, and with huge ironies. Even on the first page, Adam claims to be heading for a hospital on a hill that reminds us of his actual circumstances, which we will learn only much later; and he refers to "a Thomas Wolfe October" that offers second-time readers a poignant foreshadowing of his parents' death in an October 
his father described the same way. Such ironies occur throughout; in one of the earlier tape sequences, Adam even spills the beans about the bike trip, for those who know about the bike trip already, when he thinks, "If I can step outside myself like this, maybe I can go to other places" (p. 34).

But as in most literature, the real significance of $I \mathrm{Am}$ the Cheese is less the truth that eventually emerges from it than the way in which it emerges; what is interesting about the bike trip is less the truth it hides than the fact that it is hidden, and the way Cormier hides it. For that reason an attempt to recreate a first reading of the novel in order to show how it conceals and reveals its truths is not just desirable, but necessary. What follows is my attempt at such a recreation.

The first section of the novel implies many mysteries. A nameless person is on a bike trip: who is he? He is going to visit his father in a hospital: why is his father in hospital? He is bringing his father a gift: what is it? Novelists usually make us ask such questions at the beginnings of novels, in order to arouse our interest. But they usually quickly answer them, and then focus our attention on new developments. In I Am the Cheese, only the first question is answered quickly, and the answer turns out to be wrong: Adam Farmer is not really Adam Farmer. In keeping us in the dark about some apparently important information, Cormier extends throughout most of $I$ Am the Cheese the disorientation we usually stop feeling a short way into other novels.

In addition to those unsolved mysteries, the first section contains two details that attract attention. The person speaking tells us he is "afraid of a thousand things, a million" (p. 12), and says he has decided not to take some pills: "I wanted to do this raw, without crutches, without aid, alone" (p. 14). These comments plant the suspicion that the speaker is mentally disturbed. Then we come to the first tape sequence, which can easily be read as an interview between a therapist and a patient. The interviewer's insistence on going back to early memories, the interviewee's conviction that "the medicine was always playing tricks on him" (p. 21), his reference to "the doctor," all confirm the suspicions engendered by the first chapter: this person must be under psychiatric care. In fact, I 
assumed that the interviewee and the bike rider were the same person only because they seem to share emotional difficulties. Consequently, as I heard of the boy's past, I looked for clues to his illness. I had been made to think in the comfortably superior way that psychoanalysts think of their patients, allowed both to feel sympathy for this suffering creature and to explore the events of his life with cool detachment. I knew there was a mystery to solve here; but Cormier manipulated me into playing, not Hercule Poirot, but Sigmund Freud.

Consequently, I took for granted that the boy's frequently expressed fears were paranoid, a distortion of reality rather than a just response to it. I accepted the doctor's apparently reasonable explanations of Adam's suspicions, and thought Adam had a point when he asked himself, "Was he really manufacturing mysteries to satisfy his literary longings, finding mysteries where they did not in fact exist?" (p. 78). Given Adam's apparent illness, these reminders that less dramatic explanations are possible deflect attention from the truth.

Furthermore, having been asked to think as a psychoanalyst would, I found it hard to doubt that Brint was a psychoanalyst. I trusted Brint because Adam did not trust him, and I had been made to think of Adam as untrustworthy. Adam himself confirms that: "he was wary again, on guard, distrustful. Yet he had no reason to distrust Brint" (p. 40).

Above all, the suspicions Cormier created about Adam's sanity distracted me from questioning the biggest lie in the novel. It did not occur to me that Adam might not be, as he said he was, riding to Rutterburg. The details of this trip are weirdly unreal; but I put that down to Adam's confused state of mind. I took for granted that this was a reality he was distorting, not one he was inventing. Upon reading, I find it hard to see why I wasn't more suspicious - particularly about Adam's conversation with an old man near the beginning of his trip, who seems to be as paranoid as Adam himself. But I didn't have the evidence to realize the ironic truth in the old man's statement that "it's a terrible world out there. . you don't even know who to trust anymore" (p. 24). Trusting that the old man was indeed at a gas station, I put his distrust down to the conservatism of age. 
In the first third of the novel, then, Cormier convinced me of the truth of three falsehoods. I believed that the "doctor" was a doctor, that Adam was actually Adam and the Farmers actually the nice, normal Farmers, and that Adam was in fact on a bike trip. While Adam himself doubts the truth of all three, Cormier has manipulated me into distrusting Adam. Cormier has made me accept fantasies as truth, and assume that truth is mere delusion. He has done a Number on me.

What Brint tells Adam about the phone conversation he overhears between his mother and his aunt is true also for those who read the book: "and so, for the first time, you had actual and direct evidence that there was something wrong, that something was askew" (p. 84). But while I changed my interpretation of the situation at this point, I still didn't get it right. I still thought Adam was mentally disturbed-possibly because of some genuinely disturbing information he had learned about his family; and Cormier helped me to believe that by giving Adam some particularly intense moments of apparent paranoia: "I hate this place. The people here hate me, too... They know I'm not like them" (p. 94). But I did begin to wonder about Brint. Cormier now makes Brint's interest in psychologically insignificant information more obvious; but I noticed that, as I hadn't earlier in the novel, because of my disorientation after I shared Adam's discovery of his secret aunt. Up to that point, I'd thought I understood the sort of book I was reading. I was wrong. The mystery was not merely psychological. And if it wasn't, then why should a psychologist be involved in it? Adam says, "There was nothing to be suspicious about, until I became suspicious of everything" (p. 119). I felt the same way as I read about him, and realized I had been no better than Adam himself at penetrating deceptions, at distinguishing justified suspicion from foolish paranoia or real mysteries from psychological fancies.

But even after I became suspicious of Brint - in fact, even after I learned the truth about Adam's past, I still had no doubts about the bike trip. In fact, and in spite of many clues, I came to understand the nature of Adam's delusion only as he did so himself. My attention had been focused elsewhere: on sorting out the time sequences, on the enormity of the truth about Adam's family, on my growing suspicions of Brint. Even 
Wolfgang Iser, The Implied Reader, p. 30

D. M. Thomas, The White Hotel as I read the chapters describing the bike trip, my growing knowledge of the past led me to focus my attention more on what suitably horrible episode might have led to Adam's father being in that hospital than on the inconsistencies of the trip itself. So I was surprised to learn the truth, just as I was surprised earlier to learn the truth about Adam's family. Cormier so controlled my response to the novel that he played the exact same trick on me twice, without my suspecting the second was indeed a trick even after I learned about the first.

While my recreated first reading shows what a master craftsman Cormier is, it doesn't necessarily justify his trickery. The question remains: does Cormier's clever deception of his readers accomplish anything in addition to demanding involvement in what is, after all, an outrageously improbable plot?

It think it does. In The Implied Reader, Wolfgang Iser suggests that in good fiction, "the reader must be made to feel himself the... meaning of the novel. To do this he must actively participate in bringing out the meaning, and this participation is an essential precondition for communication between the author and the reader." Cormier's Number in $I$ Am the Cheese forces exactly that sort of participation. By tricking readers into believing lies and then revealing the truth they hide, Cormier makes us undergo the same experience Adam does. Both Adam and those who read about him believe that he is an ordinary member of an ordinary family, and overprone to foolish suspicions; that Brint is a therapist and that Adam is his mentally disturbed patient; and that Adam is on a bike trip to visit his father in a hospital. Adam's discoveries are more horrifying, and the disorientation that results from them more intense, because Cormier provides readers that same faith in untruths that Adam has, the same discoveries, and the same awesome sense of having trusted too much.

In fact, and also like Adam, learning that our first interpretations were wrong leads us to doubt our ability to interpret. In this way, I Am the Cheese is like D.M. Thomas's shattering novel The White Hotel, in which the erotic dreams that Sigmund Freud analyses as his woman patient's death wish turn out eventually to be foreshadowing her actual brutal death at Babi Yar. In comparison to that grotesque mass burial, Freud's 
clever analysis comes to seem gloriously utopian, his idea of a death-wish a lovely dream in comparison to death itself. In $I$ Am the Cheese, if we started out thinking like Freud and diagnosing Adam as a paranoid, the novel clearly teaches us to distrust the comforting logic of psychoanalytic thinking. Because our first conceptions were so wrong and so foolishly trusting, we are made to understand the justice of the sort of thinking we might otherwise dismiss as paranoia. In fact, it teaches us to think like paranoids, to replace our common sense faith in the abiding security of normalcy with the deep cynicism that our acceptance of Adam's horrifying experience implies. In other words, it teaches us that paranoia is not paranoia at all, but wisdom. Because we have acted as Adam's father was advised to act by his editor, because we have tried "to go beyond the superficial aspects of stories, to find the meanings below the surface, to root out what might be hidden or not apparent to the casual reader" (pp. 129-130), and because our logical investigation has brought us knowledge of a world as illogical and as corrupt as the one Adam's father learned of in his investigations, we have no choice but to find the cynicism convincing and thoroughly unsettling. In Iser's terms, I Am the Cheese forces us to participate in its meaning.

In his earlier novel, The Chocolate War, Cormier used a more probable set of events to express much the same cynicism about the inability of individuals to protect themselves from the corruptions of the powerful. Yet the attitudes that are so involving in $I \mathrm{Am}$ the Cheese seem merely paranoid in The Chocolate War, merely adolescent and self-indulgent-except, perhaps, to those adolescent and self-indulgent enough to share them already. In fact, The Chocolate War reads like countless other unremittingly naturalistic, unremittingly negative novels, designed to please adolescent readers by pretending that the corrupt world they describe is actually the real one. Despite their naturalistic settings, such novels are fantasies, pleasingly paranoid in their insistence that the world is not only corrupt, but out to get nice, innocent, young people just like you. For those adolescents who need to shield themselves from their growing knowledge of their personal involvement in the human condition and of the subtle confusions of good and evil in themselves and others, such fantasies are undoubtedly satisfying; for the rest of us, they seem a little silly. 
In The Chocolate War, Archie thinks that "the world was made up of two kinds of people - those who were victims and those who were victimized" (p. 80). In I Am the Cheese, Adam constantly sees himself as a victim, and assumes that everyone is out to victimize him. The fact that The Chocolate War supports Archie's crude vision makes it seem hysterical. But Adam is right. He is the only "normal" person in a crazy world. His life is a mess, and it is not his fault. Those in authority are corrupt, are power hungry, and are out to get him. In fact, and unlike The Chocolate War, I Am the Cheese turns the conventions of adolescent fiction inside out. What characters in such novels usually merely imagine about their lives (albeit with the support of their novelists) turns out to be literally true in I Am the Cheese; and meanwhile, what is literally true of the lives of characters in other novels turns out to be merely what Adam has imagined. The characters in those other novels live ordinary lives, but see them in terms of melodrama; Adam lives a melodramatic life, but poignantly imagines himself to be ordinary, an ordinary member of an ordinary family who is taking an ordinary bike trip.

Adam himself speaks of his life as "living through a Number that's the biggest one of all" (p. 180). Letting Adam do so is Cormier's biggest Number. Adam's world is so clearly unlike our own that we do not confuse it with our own; free from accusing the novel of pretending to be realistic, we can see it for the fantasy that it is, and both find it powerfully convincing and appreciate its metaphoric thrust. Anne Scott MacLeod

Anne Scott MacLeod, "Robert Cormier and The Adolescent Novel" suggests that in I Am the Cheese, "Cormier dispenses with metaphor. This stark tale comments directly on the real world of government, organized crime, large-scale bureaucracy, the apparatus of control, secrecy, betrayal, and all the other commonplaces of contemporary political life." But while the comment is direct, it is so exaggerated that it comes to stand for something both larger and more personal than politics. Adam Farmer is a far more poignant image of individual powerlessness than the self-pitying draft-dodgers of The Chocolate War.

Furthermore, the distance between Adam's plight and our own lives ought to make us realize how comparatively illegitimate our own self-pity might be. In After the First Death, published after I Am the Cheese, Cormier tells us that the young terrorist 
After the First Death Miro "felt contempt for all these American boys and girls who led their selfish, unthinking lives and thought they were so smart and brave until situations developed that showed their true worth" (p. 194). Meanwhile, Miro himself is literally what many American boys and girls seem to enjoy imagining themselves to be: alien, orphaned, "innocent," a brave idealist doomed in his fight against the corruptions of those in power - or so he thinks, for the normal American girl Kate quite rightly concludes that innocence like Miro's "could also be evil. Monstrous..." (p. 130). The contrast between the alienated terrorist and selfish, normal boys and girls is interesting because it makes obvious what $I \mathrm{Am}$ the Cheese more subtly implies: that we should be grateful for the distance between the lurid melodrama we love to imagine and the usually unexciting world we actually live in. By making readers share Adam Farmer's horrifying discovery that the secure, normal world he thought he lived in hides illogic and evil, $I A m$ the Cheese brilliantly encourages our acceptance of the ambiguous boredom and glory of normal life.

\section{References}

Cormier, Robert I Am the Cheese New York: Dell Laurel-Leaf, 1978. London: Victor Gollancz, 1977.

- - The Chocolate War New York: Dell Laurel-Leaf, 1975. London: Victor Gollancz, 1977.

- - After the First Death New York: Avon, 1980.

Iser, Wolfgang The Implied Reader: Patterns of Communication in Prose Fiction from Bunyan to Beckett Baltimore and London: Johns Hopkins, 1974.

MacLeod, Anne Scott "Robert Cormier and the Adolescent Novel; Children's literature in education, Vol. 12, No. 2, 1981, p. 76.

Thomas, D. M. The White Hotel London: Victor Gollancz, 1981. New York: Viking, 1980. 